\title{
CRYPTO-ASSETS IN THE EU AND POLISH REGULATORY FRAMEWORK REGARDING FINANCIAL INSTRUMENTS
}

\begin{abstract}
Crypto-assets are private, convertible, digital tokens that are managed in a decentralized way using technology called distributed ledger technology (DLT). The term is not limited only to decentralized virtual currencies, but also commodities, digital goods and services. As such they can be considered an addition to a financial investment portfolio, being an alternative to traditional instruments, such as stocks, bonds or cash. However, wide use of crypto-assets is being currently hampered by lack of regulations followed by uncertainties as to the legal qualification of crypto-assets and consequences of investments in such instruments.
\end{abstract}

From that perspective, it seems crucial to answer a question whether crypto-assets can be considered financial instruments in the light of the current Directive on Markets in Financial Instruments (so called MiFID II) at the EU level and national acts that implemented relevant provisions of MiFID II (in Poland it is the Act on Trading in Financial Instruments). Since neither the EU nor Polish legislator provided a clear answer to that question, some indications can be found only in official statements of regulatory authorities and the doctrine, which however are not always consistent with each other. Furthermore, the Member States used different legislative techniques in the process of implementing MiFID II so the nomenclature can differ.

The article discusses the diverse approaches to crypto-assets in the interpretation of the EU and Polish legislation concerning financial instruments as well as implications of such differences.
Keywords: crypto-assets, blockchain, ESMA, MiFiD II, Act on Trading in Financial Instruments, securities

\section{Introduction}

Together with the emergence of Bitcoin and the underlying blockchain technology, the new class of assets - crypto-assets - has developed. As the term itself indicates, the very fundament of crypto-assets is advanced cryptography that enables secure execution of transactions. They can be defined as digital assets which utilize cryptography, peer to peer networks, and a public ledger to regulate the generation of new units, verify the transactions, and secure the transactions without the intervention of any intermediary [Caponera, Gola 2019, p. 5]. For better understanding of the term and differentiation of the variety of crypto-assets, in the literature the following classification was introduced: cryptocurrencies (serving as means of exchange, store of value, and unit of account), crypto commodities (used to provide services or functionalities) and crypto tokens (that represent participations in real physical undertakings, companies, or earnings streams, or an entitlement to dividends or interest payments) [Burniske, Tatar 2017 p. 8].

Similar classification has been applied by the Swiss regulator - Financial Market Supervisory Authority (FINMA) in the document that can be considered the first and relatively comprehensive official statements on how to understand crypto-assets and how to apply to them national regulations on financial instruments. As a reaction to increasing 
number of ICOs (Initial Coin Offerings) ${ }^{1}$ and transactions involving cryptocurrencies, on 16 February 2018 FINMA published guidelines on how it intends to apply financial market legislation in handling enquiries from ICO organisers. The main purpose of the guidelines was to indicate which of the crypto-assets existing on the market can be considered as financial instruments and therefore subject to the Swiss Financial Market Infrastructure Act. FINMA defined tokens as blockchain-based units issued by the ICO organizer and divided them into three groups:

1. payment tokens (cryptocurrencies),

2. utility tokens,

3. asset tokens,

stating that only the last ones will always be treated as financial instruments [2018, p. 3]. Very similar approach was later introduced by the EU regulator - European Securities and Markets Authority (ESMA). I argue that this approach has a chance to become a standard in the development of legal regulations concerning crypto-assets since, within the EU single market, the standardisation of terms and provisions is a natural and positive tendency. On the other hand, thanks to the legislative technique used in MiFID II [Directive 2014/65/EU of the European Parliament and of the Council of 15 May 2014 on markets in financial instruments and amending Directive 2002/92/ EC and Directive 2011/61/EU] that gave the EU Member States freedom to choose means and methods to achieve the goals set out in the Directive, the Member States have, with varying intensity and unambiguity, transposed EU standards into national regulations differently. Consequently, their interpretations of the term 'financial instruments' are not consistent. Using the example of the Polish definition of financial instruments adopted in the Act on Trading in Financial Instruments [Journal of Laws of 2005 , no. 183 , item 1538], in this article I would like to present how the differences in nomenclature can hamper

\footnotetext{
1 Initial Coin Offering means using digital tokens to raise capital for a venture. It is an open call for funding to raise money through cryptocurrencies (an " $(. .$.$) open call, through$ the Internet, for the provision of cryptocurrencies in exchange for tokens generated through smart contacts and relying on the blockchain technology, allowing the pledger to enjoy an exclusive right or reward or financial claim (...)", in: Adhami S., Giudici G., Martinazzi S. (2018), Why Do Businesses Go Crypto? An Empirical Analysis of Initial Coin Offerings, "Journal of Economics and Business", vol. 100, p. 66. Due to the format of this article, the legal qualification of ICO is not discussed here.
}

the standardisation process, resulting in an even more urgent need of intervention of a relevant legislator.

\section{ESMA's approach}

On 9 January 2019, ESMA published a comprehensive statement on the phenomenon commonly known as an Initial Coin Offerings (ICOs) and crypto-assets. Attention was paid mainly to the problem of the lack of transparent rules defining whether and which laws apply to these issues and the high level of risk associated with fraud, cyber-attacks, money laundering and market manipulation with regard to crypto-assets. Therefore, as ESMA stated in its Advice, key consideration for regulators was the legal status of crypto-assets, as it determines whether relevant legal provisions are likely to apply, and if so - which ones. According to the document, crypto-assets are a type of private assets that depends primarily on cryptography and Distributed Ledger Technology (DLT) as part of their perceived or inherent value that is not issued nor guaranteed by any central bank. There are a wide variety of crypto-assets, ranging from so-called cryptocurrencies or virtual currencies, like Bitcoin, to so-called digital tokens issued through Initial Coin Offerings. Some crypto-assets have attached profit or governance rights while others provide some consumption value. Others are meant to be used as a means of exchange and many have hybrid features [ESMA 2019, p. 4].

ESMA in its Advice focused primarily on the legal qualification of crypto-assets under MiFID II as a financial instrument. Financial instruments are defined in Article 4(1) (15) of MiFID II as those "instruments specified in Section C of Annex I." These are i.e. 'transferable securities', 'money market instruments', 'units in collective investment undertakings' and various derivative instruments. In order to determine whether crypto-assets can be included in any of those groups, ESMA divided them into four categories:

1. investment-type,

2. utility-type,

3. payment-type and hybrids of investment-type,

4. utility-type and payment-type.

ESMA observed that crypto-assets can have different features and purposes. "Some crypto-assets, sometimes referred to as 'investment-type' crypto-assets may have some profit rights attached, like equities, equity-like instruments or non-equity instruments. Others, so-called 'utility-type' crypto-assets, provide some 'utility' or consumption 
rights, e.g., the ability to use them to access or buy some of the services/products that the ecosystem in which they are built aims to offer. Others, so-called 'payment-type' crypto- assets, have no tangible value, except for the expectation they may serve as a means of exchange or payment to pay for goods or services that are external to the ecosystem in which they are built. Also, many have hybrid features or may evolve over time" [ESMA 2019, p. 8].

ESMA decided that pure payment-type and utility-type tokens will almost certainly not be considered as financial instruments but investment-type ones and hybrids can be considered as transferable securities under MiFID II. As a consequence, the offering of those type of crypto-assets will fall under the scope of all relevant EU regulations concerning business activity on financial markets. The Advice further provides interested entities with a list of potentially applicable legal provisions, besides MiFID II, like e.g.:

- The Prospectus Directive,

- The Transparency Directive,

- The Market Abuse and Short-Selling Regulation,

- The Settlement Finality Directive,

- The Central Securities Depositories Regulation etc. Interestingly, in order to determine the legal qualification of crypto-asses thus organised in specific Member States, ESMA undertook a survey among national regulators. After receiving from ESMA a sample of 6 different crypto-assets thoroughly described, the regulators were to decide whether according to the national laws, the crypto-assets could be qualified as financial instrument. The responses varied among regulators from 29 countries (27 EU Member States- Poland did not provide answers to the survey, Lichtenstein and Norway). Most of them confirmed that investment-type crypto-assets are financial instruments under national laws and pure payment-type or pure utility-type ones are not. The assessments regarding hybrid-type crypto-assets varied significantly.

Importantly, the vast majority of the regulators did not believe that any national rules in place would capture any of the six case studies.

\section{Crypto-assets under the Polish Act on Trading in Financial Instruments}

ESMA did not provide any explanation in its Advice why Poland did not participate in the survey. One of the reasons (apart from possible negligence) can be the difficulty to assess whether any of the crypto-assets are financial instruments under Polish laws.

The basic legal definition of financial instruments in Polish regulations of capital markets, is included in the Act on Trading in Financial Instruments. According to the Article 2 paragraph 1 of the Act, financial instruments within the meaning of the Act are: securities (also bills of exchange and checks, which, however, Article 1 of the Act excludes from its scope) and financial instruments that are not securities, among which are listed:

- units of participation in collective investment institutions,

- money market instruments,

- derivatives related to the transfer of credit risk,

- contracts for difference,

- options,

- futures,

- swaps,

- forward contracts,

- other derivatives meeting the requirements specified in this provision.

In professional literature, it has been pointed out that the definition of a financial instrument included in the Act is of a technical nature. It does not determine a uniform construction of property rights defined as financial instruments in the Polish civil law [Sójka 2015, p. 17].

As it was mentioned above, ESMA by classifying certain types of crypto-assets, namely investment-type and hybrids as financial instruments, determined that they should most likely be treated as transferable securities. And as in MiFID II, this term is defined as "any other securities giving the right to acquire or sell any such transferable securities or giving rise to a cash settlement determined by reference to transferable securities, currencies, interest rates or yields, commodities or other indices or measures", in Poland the legal definition of securities is significantly different and has a long history and legal tradition. Therefore, not only there is a 'numerus clausus' rule regarding securities (disputable however in the doctrine), which practically means that new types of securities can be created only by means of a legal act, but also the Article 3 paragraph 1 of the Act on Trading in Financial Instruments defines securities simply by giving a list of their possible types. Having also in mind that securities can only have one of three possible forms in Polish legal system: document, book entry form or other in accordance with separate provisions, it seems that without the intervention of the legislator, the qualification 
of crypto-assets as securities under Polish law will be impossible. In the meantime, there is no official statement of the Polish Financial Supervision Authority (Komisja Nadzoru Finansowego- KNF) determining legal character of crypto-assets, regardless of their type or purpose. Available communications or press releases of KNF concerning cryptocurrencies and ICOs are rather aimed at deterring, indicating risks, uncertainties and possible administrative and criminal sanctions if the competent authorities recognize that the activity in the field of crypto-assets was conducted in breach of law ${ }^{2}$.

\section{Conclusions}

Growing interest in investing in crypto-assets on financial markets combined with the lack of comprehensive regulation of this phenomenon both in the EU and national law, made the competent regulatory authorities responsible for informing the market how they intend to evaluate activities in this area and recognize possible violations of financial market laws. As it was presented in the article, such documents gave the first semi-binding, yet official, definitions of crypto-assets and attempts to classify them. Importantly, universal formulas to determine their legal qualification were proposed, namely economic function of the crypto-assets, what enabled the assessment whether they can be treated as financial instruments.

However, in my opinion there are more far-reaching implications of these actions. To begin with, it means that 9 years after the emergence of the first crypto-asset (Bitcoin) and the lack of universal qualifications and definitions in legal provisions, the regulators have decided to clarify uncertainties as to the application of legal provisions on financial instruments themselves in order to protect investors and the market. In this way, even though any guidelines, reports or official statements cannot be

2 Examples: Komisja Nadzoru Finansowego (2018), Komunikat $\mathrm{w}$ sprawie funkcjonowania giełd i kantorów kryptowalut [online], www.knf.gov.pl/?articleId=61994\&p_id=18, access as of 30 April 2019; Komisja Nadzoru Finansowego \& Narodowy Bank Polski, Uważaj na kryptowaluty [online], www. uwazajnakryptowaluty.pl, access as of 30 April 2019; Komisja Nadzoru Finansowego (2017), Komunikat w sprawie sprzedaży tzw. monet lub tokenów (Eng. Initial Token Offerings ITOs or Initial Coin Offerings - ICOs) [online], www.knf.gov. $\mathrm{pl} / \mathrm{o} \_$nas $/$komunikaty? articleId $=60178 \& \mathrm{p} \_\mathrm{id}=18$, access as of 30 April 2019. regarded as legally binding, they will have a great (and hopefully positive) impact on markets of crypto-assets.

On the other hand, the issuance of the ESMA's Advice will not significantly allay the doubts of the participants of crypto-markets. The differences in the methods of implementing the definition of financial instruments from MiFID II in the Member States, as it was presented on the Polish example, can create further uncertainties and interpretation problems. Fortunately, similar formulas of assessing whether a given crypto-asset is a financial instrument have begun to be created by national authorities. Even this, however, will not rule out completely the urgent necessity to change the existing legislation or add provisions to respond to the unique characteristics of the sector, e.g. the decentralized nature of the underlying technology, risk of forks, and the custody of the assets. Hopefully, the complex regulation on crypto-assets will be introduced at the European level, because differences in regulations and interpretations resulting from different assumptions of the European and national legislator may lead to different conclusions as to the scope of the provisions on financial instruments. From the perspective of the fundamental principles of the EU single market, this phenomenon should be assessed as extremely negative.

\section{Bibliography}

Adhami S., Giudici G., Martinazzi S. (2018), Why Do Businesses Go Crypto? An Empirical Analysis of Initial Coin Offerings, "Journal of Economics and Business" vol. 100.

Burniske C., Tatar J. (2017), Cryptoassets The Innovative Investor's Guide to Bitcoin and Beyond, McGraw-Hill Education, New York.

Caponera A., Gola C. (2019), Aspetti economici e regolamentari delle «cripto-attività», "Questioni di Economia e Finanza (Occasional Papers)” no. 484.

ESMA (2019), Advice on Initial Coin Offerings and Crypto-Assets [online], www.esma.europa.eu/sites/default/ files/library/esma50-157-1391_crypto_advice.pdf, access as of 30 April 2019.

FINMA (2018), Guidelines for enquiries regarding the regulatory framework for initial coin offerings (ICOs) [online], www.finma.ch/en/news/2018/02/20180216mm-ico-wegleitung/, access as of 30 April 2019.

Komisja Nadzoru Finansowego (2017), Komunikat w sprawie sprzedaży tzw. monet lub tokenów (Eng. Initial Token Offerings - ITOs or Initial Coin Offerings - ICOs) [online], www.knf.gov.pl/o_nas/komunikaty?articleId=60178\&p_id=18, access as of 30 April 2019. 
Komisja Nadzoru Finansowego (2018), Komunikat w sprawie funkcjonowania giełd i kantorów kryptowalut [online], www.knf.gov.pl/?articleId=61994\&p_id=18, access as of 30 April 2019.

Komisja Nadzoru Finansowego \& Narodowy Bank Polski, Uważaj na kryptowaluty [online], www.uwazajnakryptowaluty.pl, access as of 30 April 2019.

Romanowski M. (2016), Zasada numerus clausus papierów wartościowych [in:] Szumański A. (red.), Prawo papierów wartościowych. System Prawa Prywatnego tom 18, C.H.Beck, Warszawa.

Sójka T. (red.) (2015), Komentarz do ustawy o obrocie instrumentami finansowymi, Prawo rynku kapitałowego. Komentarz, Lex, Warszawa.

What is a cryptoasset? Types of cryptoassets [online], www. feedough.com/what-is-a-cryptoasset-types-of-cryptoassets-ultimate-guide/, access as of 30 April 2019.

\section{Legal Acts}

Directive 2014/65/EU of the European Parliament and of the Council of 15 May 2014 on markets in financial instruments and amending Directive 2002/92/EC and Directive 2011/61/EU (OJ EU L 173 of 12.6.2014, p. 349).

Act of 29 July 2005 on Trading in Financial Instruments (Journal of Laws of 2005, no. 183, item 1538).

\section{Author biography}

Katarzyna Ziółkowska - PhD student at the Institute of Legal and Administrative Sciences of the Faculty of Law and Administration at the University of Warsaw and a member of the Research Centre on the Legal Aspects of Blockchain Technology. Professionally associated with the Polish National Centre for Research and Development. 